\title{
Decay-accelerating Factor Is Expressed on Vascular Smooth Muscle Cells in Human Atherosclerotic Lesions
}

\author{
Paul S. Seifert and Göran K. Hansson \\ Department of Clinical Chemistry, Gothenburg University, Sahlgren's Hospital, S-413 45 Gothenburg, Sweden
}

\begin{abstract}
Decay-accelerating factor (DAF) is a constitutively expressed plasma membrane glycoprotein on blood cells and endothelium that inhibits cell surface $\mathrm{C} 3 / \mathrm{C5}$ convertase formation, thus inhibiting complement activation and protecting cells from lysis by the terminal complement components. Using monoclonal anti-DAF antibodies in conjunction with anti-smooth muscle cell (SMC)-specific myosin antibodies, it was found by immunohistochemistry that vascular SMC in advanced human carotid atherosclerotic lesions express DAF antigen. The percentage of DAF-positive SMC ranged from 20 to $60 \%$ between different patient samples and SMC DAF expression was limited to SMC in the lesion proper. Normal arterial wall SMC exhibited no DAF-specific immunostaining. Essentially $100 \%$ of passaged cultured vascular SMC derived from normal human uterine artery, or from umbilical vein, expressed DAF as assessed by immunocytochemistry. A 68-kD band was observed on SDS-PAGE autoradiograms of DAF-immunoprecipitated radiolabeled cultured SMC extracts. Sensitization of rabbit erythrocytes with DAF-containing SMC extracts conferred protection against complement-mediated hemolysis in normal human serum and the protective effect could be reversed by treatment with anti-DAF antibodies. We conclude that DAF is induced on vascular SMC during atherogenesis and in culture.
\end{abstract}

\section{Introduction}

Several lines of evidence indicate that the complement system participates in atherosclerotic lesion development (1). Terminal C5b-9 complexes, a stable end product of the complement activation sequence, have been observed in lesions by immunohistochemistry (2). They have also been quantitated in human aortic lesion extracts using an enzyme-linked immunoabsorption technique (3). Antibodies recognizing native complement proteins reveal that all components required for activation are present in lesions $(4,5)$. Furthermore, lesion components released into the bloodstream from ulcerated plaques appear to activate complement intravascularly $(6,7)$, demonstrating that complement activating structures are present in plaques.

Prime candidates for lesion activating structures are hydroxyl group-bearing lipids and necrotic cells. Crystalline cho-

Address reprint requests to Dr. Paul S. Seifert, Department of Clinical Chemistry, Gothenburg University, Sahlgren's Hospital, S-413 45 Gothenburg, Sweden.

Received for publication 24 January 1989.

J. Clin. Invest.

(C) The American Society for Clinical Investigation, Inc. 0021-9738/89/08/0597/08 \$2.00

Volume 84, August 1989, 597-604 lesterol, which exists predominantly in the core region of plaques $(8,9)$, activates complement in vitro generating $\mathrm{C} 3 \mathrm{a}$ (des arg), C5a (des arg), and C5b-9 complexes (10). Cell organelles, such as intermediate filaments and mitochondria, are complement activators $(11,12)$ and would potentially be exposed to complement proteins following cell damage and necrosis (13). There is evidence that the plasma membrane under conditions of injury also becomes a complement-activating surface (14). Necrotic cells in ischemic myocardium have been observed to stain for complement components including the C5b-9 terminal complex $(15,16)$.

During complement activation, $\mathrm{C} 3 \mathrm{~b}$ molecules are generated that can potentially bind to cell surfaces to form $\mathrm{C} 3 / \mathrm{C} 5$ convertases, thus amplifying the activation process and possibly leading to cell lysis via C5b-9 formation. Cell surface C3 convertase formation is inhibited on cells that bear decay-accelerating factor (DAF) ${ }^{1}(17-19)$, membrane cofactor protein (gp 45-70) $(20,21)$, or complement receptor type 1 (CR1) (22, 23). This includes most blood cells (20-28). DAF is an $\sim 70$ $\mathrm{kD}$ plasma membrane glycoprotein that inhibits convertase formation by displacing $\mathrm{C} 2 \mathrm{a}$ and $\mathrm{Bb}$ from activator bound $\mathrm{C} 4 \mathrm{~b}$ and $C 3 b$, respectively $(18,19)$. In the membranous form, it can only inhibit convertases, which result from $\mathrm{C} 3 \mathrm{~b} / \mathrm{C} 4 \mathrm{~b}$ binding to the cell surface in which DAF is incorporated (29). The importance of DAF is exemplified in the acquired disorder, paroxysmal nocturnal hemoglobinuria, wherein DAF-deficient blood cells are susceptible to lysis by autologous complement (30).

Regulatory mechanisms for complement activation in the arterial wall have not yet been defined. Vascular smooth muscle cells (SMC) are virtually the only cell-type in normal arterial tunica intima and media, and whether they possess cell surface complement regulatory molecules is unknown. The presence of C5b-9 complement complexes in early as well as advanced atherosclerotic lesions suggests that complement activation is a continuous feature of lesion development. Since activation of complement with C5b-9 formation can damage or lyse cells and thus contribute to lesion necrosis, we investigated whether vascular SMC express DAF. We report that DAF is present on a population of SMC within the lesion but is not detectable on SMC of normal arterial wall. Our findings indicate that DAF expression can be induced on a normally DAF-negative cell type in a pathologic condition involving complement activation and that DAF may function to regulate complement activation in atherogenesis.

\section{Methods}

Buffers, reagents, and antibodies. Isotonic veronal-buffered saline, $\mathrm{pH}$ 7.4 , consisted of $2.5 \mathrm{mM}$ barbital, $73 \mathrm{mM} \mathrm{NaCl}, 2.5 \%$ dextrose, 0.1

1. Abbreviations used in this paper: CR1, complement receptor type 1; CR2, complement receptor type 2; DAF, decay-accelerating factor; $E^{\text {h }}$, human erythrocytes; $E^{r}$, rabbit erythrocytes; SMC, smooth muscle cells; SMM, smooth muscle cell-specific myosin. 
$\mathrm{mM} \mathrm{CaCl}_{2}, 0.5 \mathrm{mM} \mathrm{MgCl}_{2}$, and $1 \%$ gelatin $\left(\mathrm{DGVB}^{2+}\right)$. Isoionic veronal buffer for ion chelation contained $2.5 \mathrm{mM}$ barbital, $146 \mathrm{mM}$ $\mathrm{NaCl}, 1 \%$ gelatin, and $10 \mathrm{mM}$ EDTA (GVB-EDTA), or $2 \mathrm{mM} \mathrm{MgCl}$ with $8 \mathrm{mM}$ EGTA (GVB-MgEGTA). Hanks' balanced salt solution was purchased from Gibco Laboratories (Grand Island, NY) and PBS contained $150 \mathrm{mM} \mathrm{NaCl}$ and $10 \mathrm{mM}$ sodium phosphate buffer, $\mathrm{pH}$ 7.2. Tris-Triton buffer contained $50 \mathrm{mM}$ Tris- $\mathrm{HCl}, \mathrm{pH} 7.4 ; 190 \mathrm{mM}$ $\mathrm{NaCl} ; 6 \mathrm{mM}$ EDTA; $100 \mathrm{U} / \mathrm{ml}$ Trasylol; and 2.5\% Triton X-100.

Mouse monoclonal antibodies to human DAF (clones IA10 and IIH6) and SMC $\alpha$-actin were generously provided by Dr. Victor Nussenzweig (New York University Medical Center, New York) (26) and Dr. Giulio Gabbiani (University of Geneva, Geneva, Switzerland) (31), respectively, and rabbit polyclonal antibodies to human SMCspecific myosin (heavy chain) (SMM) were kindly provided by Dr. David Larson (Boston University School of Medicine, Boston, MA) (32). Anti-LeuM3, a mouse monoclonal antibody recognizing the human monocyte-macrophage-specific $\mathrm{CD} 14$ antigen and mouse monoclonal antibodies to human complement receptors type 1 (CR1) and type 2 (CR2) and HLA-DR were purchased from Becton Dickinson \& Co., Inc. (Mountain View, CA). Biotinylated anti-mouse immunoglobulin, fluorescein-conjugated streptavidin and Texas Red-conjugated streptavidin were purchased from Amersham Corp. (Amersham, UK). Rhodamine-conjugated swine anti-rabbit immunoglobulin and anti-von Willebrand factor antigen were obtained from Dakopatts (Copenhagen, Denmark). DiI-acetylated LDL was purchased from Biogenesis (Bournemouth, UK).

Vascular tissue. Atherosclerotic lesions from internal carotid arteries were obtained from patients undergoing endarterectomy surgery and nonatherosclerotic arterial tissue was obtained from the aortic base during coronary bypass surgery and from uterine arteries during hysterectomy. Tissues were transported to the laboratory in ice-cold HBSS, rinsed in PBS, embedded in OCT compound (Miles Laboratories, Inc., Naperville, IL) and snap-frozen in liquid nitrogen-cooled $n$-hexane. Tissue samples were stored at $-70^{\circ} \mathrm{C}$ until frozen sections were made. Umbilical cords were obtained $24-48 \mathrm{~h}$ postpartum.

Plaque cell isolation. Cells were isolated from internal carotid artery atherosclerotic plaques under aseptic conditions as previously described (33). Briefly, PBS-washed arterial tissue was finely minced with scissors and then digested with $900 \mathrm{U} / \mathrm{ml}$ collagenase (type IV; Sigma Chemical Co., St. Louis, MO) in PBS containing $1 \mathrm{mg} / \mathrm{ml}$ trypsin inhibitor (Sigma), $0.4 \%$ BSA (Sigma) and $0.9 \mathrm{mM} \mathrm{CaCl}_{2}$. Cells were separated from large debris by passing the tissue extract through a 150 $\mu$ m nylon mesh filter and the cells were then plated into chamber slides (Miles Scientific) or cytospin preparations were made. Immunocytochemistry was performed on these cells as described below for frozen sections of tissue.

Immunohistochemistry. Frozen sections of arterial tissue were processed for immunohistochemistry as described (34). Briefly, ethanolfixed tissue sections were incubated with primary antibodies and then developed with biotinylated secondary antibodies and a streptavidinconjugated fluorescent compound. For double staining, the same tissue section was then treated with the second primary antibody and developed with a fluorescein or rhodamine-conjugated secondary antibody. Control stains were performed with nonrelevant antibodies of the same immunoglobulin subclass or by omission of the primary antibody. Optimal dilutions of SMM antibodies were determined on frozen sections of normal artery and on cultured SMC. Determination of the optimal anti-DAF antibody concentration was performed by incubating serial dilutions of antibody on cultured monocytes. The working concentration of anti-DAF antibody used $(250 \mathrm{ng} / \mathrm{ml})$ was similar to that used in a previously reported immunohistochemical study employing the same antibody (24).

Cell culture. SMC were obtained from human uterine arteries as described (35) or from umbilical veins as follows. Umbilical cords $<48$ $h$ old were cannulated, rinsed of blood with $37^{\circ} \mathrm{C}$ PBS, and filled with $0.1 \%$ collagenase (Type IV; Sigma) for $15 \mathrm{~min}$. After several lumenal rinses with RPMI 1640 (Gibco) to remove the endothelial cells, fresh collagenase was introduced for $15 \mathrm{~min}$. The liberated SMC were col- lected in RPMI, pelleted, and resuspended in RPMI containing antibiotics, $10 \%$ heat-inactivated FCS and $10 \%$ heat-inactivated normal human serum (35). Seeding densities were $4 \times 10^{5} \mathrm{cells} / \mathrm{ml}$ and medium was changed every $4 \mathrm{~d}$. Cells were grown in standard tissue culture flasks (Nunc, Roskilde, Denmark) and passaged at near confluence at a 1:3 ratio using a $0.25 \%$ trypsin-EDTA solution (Gibco). Cell-type homogeneity was checked by staining cultured cells with anti-SMM; anti-von Willebrand factor, anti-LeuM3 and dil-acetylated LDL. From this assessment, cultures after third passage were found to be $99 \%$ SMC myosin positive and only a $1 \%$ contamination of endothelial cells or macrophages.

Cell labeling and immunoprecipitation. Cell surface labeling of DAF was performed using ${ }^{125} \mathrm{I}$ according to the technique of Kinoshita et al., (26). For these experiments, SMC were first removed from culture flasks with a rubber policeman, pelleted, and washed once in PBS. Approximately $10^{9}$ cells $/ \mathrm{ml}$ were then labeled in suspension with 1 $\mathrm{mCi}$ of ${ }^{125} \mathrm{I}$ using Iodogen coated tubes (Pierce Chemical Co., Rockford, IL). Human erythrocytes $\left(E^{\mathrm{h}}\right)$ were simultaneously labeled (1 $\mathrm{mCi} / 2 \times 10^{8} \mathrm{E}^{\mathrm{h}}$ ) to provide a positive control. After radioiodination, the cells were centrifuged through FCS and repeatedly washed until the radioactivity in the wash supernatant was $<10 \%$ of the radioactivity initially added. Cell pellets were resuspended in $400 \mu \mathrm{l}$ of $20 \mathrm{mM}$ Tris- $\mathrm{HCl}, \mathrm{pH} 7.5$, containing $1 \%$ SDS and $100 \mathrm{U} / \mathrm{ml}$ Trasylol (Bayer, Stockholm, Sweden) and treated further as described (24).

For metabolic labeling of DAF, three to six $175-\mathrm{mm}^{2}$ culture flasks containing SMC at near confluence were rinsed with methionine-free RPMI and the cells cultured for $26 \mathrm{~h}$ in methionine-free RPMI containing $50 \mu \mathrm{Ci} / \mathrm{ml}\left[{ }^{35} \mathrm{~S}\right]$ methionine (Amersham) and $10 \%$ heat-inactivated FCS. After three washes with complete RPMI, PBS containing 1 mM PMSF and $0.1 \mathrm{mM}$ leupeptin was added and the cells detached using a rubber policeman. The pelleted cells were resuspended in $\mathbf{4 0 0}$ $\mu \mathrm{l}$ of $20 \mathrm{mM}$ Tris- $\mathrm{HCl}$ buffer as with ${ }^{125} \mathrm{I}$-labeled SMC and processed further as described (24).

The immunoprecipitation procedure followed was essentially that of Medof et al., (24). Cell extract supernatants $(0.75$ to $1.5 \mathrm{ml})$ were incubated with $300 \mu \mathrm{l}$ of $10 \%$ protein A-Sepharose (Pharmacia, Uppsala, Sweden) in Tris-Triton buffer for $2 \mathrm{~h}$ at $23^{\circ} \mathrm{C}$. After centrifugation, the supernatants were transferred to new tubes and incubated with anti-DAF antibody $(5 \mu \mathrm{g} / \mathrm{ml})$ or control antibody $(5 \mu \mathrm{g} / \mathrm{ml})$ for $2 \mathrm{~h}$ at $20^{\circ} \mathrm{C}$. Fresh $10 \%$ protein A-Sepharose was then added $(100 \mu \mathrm{l})$ for 1 $\mathrm{h}$ to precipitate immune complexes. After centrifugation at $10,000 \mathrm{~g}$ for $5 \mathrm{~min}$, the precipitate was washed twice in Tris-Triton buffer and the final pellet resuspended in $50 \mu$ l of SDS-PAGE sample buffer and boiled for $10 \mathrm{~min}$. The immunoprecipitated samples were subjected to $3.5 \% / 7.5 \%$ SDS-PAGE. The gels were then fixed in 7\% acetic acid for $30 \mathrm{~min}$ followed by incubation in Amplify (Amersham) for $20 \mathrm{~min}$. Autoradiographs of dried gels were made with X-omat XAR film (Eastman Kodak Co., Rochester, NY), $-70^{\circ} \mathrm{C}$.

Assessment of SMC DAF function. The analysis of SMC DAF functional activity utilizing rabbit erythrocytes $\left(E^{r}\right)$ as indicator cells was performed essentially as according to Medof et al., (29). $\mathrm{E}^{\mathrm{r}}$ were washed three times in $\mathrm{DGVB}^{2+}$ and adjusted to $10^{8} \mathrm{E}^{\mathrm{r}} / \mathrm{ml}$. SMC extract, prepared by resuspending PBS washed SMC in $20 \mathrm{mM}$ Tris-HCl, pH 7.5, containing $1 \%$ SDS and $100 \mathrm{U} / \mathrm{ml}$ Trasylol, was exhaustively dialyzed against $\mathrm{DGVB}^{2+}$ at $4^{\circ} \mathrm{C}$ and diluted in $\mathrm{DGVB}^{2+}$ as indicated. Various dilutions of extract ( $1 \mathrm{ml}$ final volume) or extract buffer were incubated with $1 \mathrm{ml}$ of $\mathrm{E}^{\mathrm{r}}$ for $30 \mathrm{~min}$ at $20^{\circ} \mathrm{C}$. After three washes in DGVB $^{2+}$, the extract-sensitized $\mathrm{E}^{\mathrm{r}}$ were resuspended in $1 \mathrm{ml}$ of GVBMgEGTA. $100 \mu$ l of extract sensitized $\mathrm{E}^{\mathrm{r}}\left(10^{8} \mathrm{E}^{\mathrm{r}} / \mathrm{ml}\right)$ were then reacted with GVB-MgEGTA dialyzed pooled normal human serum for 15 $\min$ at $20^{\circ} \mathrm{C}$. $1.8 \mathrm{ml}$ of cold GVB-EDTA was then added to stop the reaction and after centrifugation the degree of hemolysis was assessed using a spectrophotometer set at $412 \mathrm{~nm}$.

\section{Results}

$D A F$ in atherosclerotic lesions. Atherosclerotic internal carotid arteries were obtained during endarterectomy surgery from 
patients experiencing transitory ischemic attacks. These lesions represent complicated plaques. A grossly thickened tunica intima was present, usually with an irregular lumenal surface and occasional medial involvement. Lesions exhibited a fibrous cap containing variable amounts of SMC, macrophages and T lymphocytes, and a lipid-rich necrotic core (34). SMC were identified with polyclonal anti-SMC myosin antibodies (SMM) (32). The results obtained with these antibodies were confirmed with antibodies against SMC $\alpha$-actin. SMM antibodies did not stain blood monocytes, 7-d-old cultured monocytes or complement receptor-positive cells in germinal centers of human lymph node. In contrast, anti-DAF antibodies reacted with all three of these cell types.

19 patient samples of carotid atherosclerotic lesions were stained with anti-DAF monoclonal antibody and all were found to exhibit DAF-specific immunofluorescence (Fig. 1). Both cellular and extracellular DAF staining was apparent. The intensity of extracellular DAF staining was generally greatest near to the vascular lumen. Cellular and extracellular DAF was limited to the area of disease involvement, whereas normal tunica media, when present in the lesion samples, was DAF-negative. Extracellular DAF antigen was granular in tissue spaces but diffuse along connective tissue fibers. Cellular DAF antigen was localized to both macrophages and SMC. DAF expressing macrophages were detected using the CD14 monoclonal antibody, anti-LeuM3, in serial sections (data not shown). DAF expression by vascular SMC was observed after double-labeling frozen sections with anti-DAF antibody and anti-SMM. Not all myosin-positive cells reacted with antiDAF antibody (Fig. 2). The number of DAF/SMC-myosin costained cells varied between patient samples ranging from 20 to $60 \%$ of the total SMC myosin-stainable cell population. Normal arterial tissue was negative for DAF-specific immunofluorescence except at the lumenal border (Fig. 3).
Vascular SMC in atherosclerotic lesions are commonly embedded in a connective tissue sheath $(36,37)$. Therefore, to be certain that DAF staining was due to cell surface antigens and not molecules associated with the SMC basal lamina, carotid artery tissue samples were digested with collagenase in vitro to liberate the plaque cells (33). Isolated cells were then either stained as cytospin preparations or after a 2-d culture period (to allow adherence of live cells to a substratum). A costaining of cells with SMM and anti-DAF antibodies confirmed the results obtained with frozen sections (Fig. 4). A similar range in the number of DAF expressing SMC was obtained with this technique as compared with frozen sections. As shown in Fig. 4, DAF-positive SMC isolated from lesions often contained substantial cytoplasmic lipid deposits and not all SMC expressed DAF antigen.

$D A F$ expression on cultured vascular SMC. Fourth to seventh passage SMC isolated from either umbilical veins or uterine arteries were assessed for DAF expression by immunocytochemistry. Essentially $100 \%$ of the cells stained for DAF in a granular pattern evenly distributed over the surface of the cells (Fig. 5).

DAF expression on cultured vascular SMC was confirmed by SDS-PAGE analysis of cell membrane immunoprecipitates. Cultured umbilical vein or uterine artery SMC surface labeled with ${ }^{125}$ I and immunoprecipitated with monoclonal anti-DAF antibodies exhibited a $68-\mathrm{kD}$ band on autoradiographs of SDS-polyacrylamide gels (Fig. 6). Human erythrocytes used as a positive control exhibited a DAF-specific band at $70 \mathrm{kD}$. SMC metabolically labeled with $\left[{ }^{35} \mathrm{~S}\right]$ methionine also yielded a DAF-specific 68-kD band (data not shown).

Functional activity of SMC DAF. To determine whether the SMC DAF antigen demonstrated by immunologic techniques exhibited functional DAF activity, a hemolytic bioassay was performed. This technique exploits the fact that rabbit

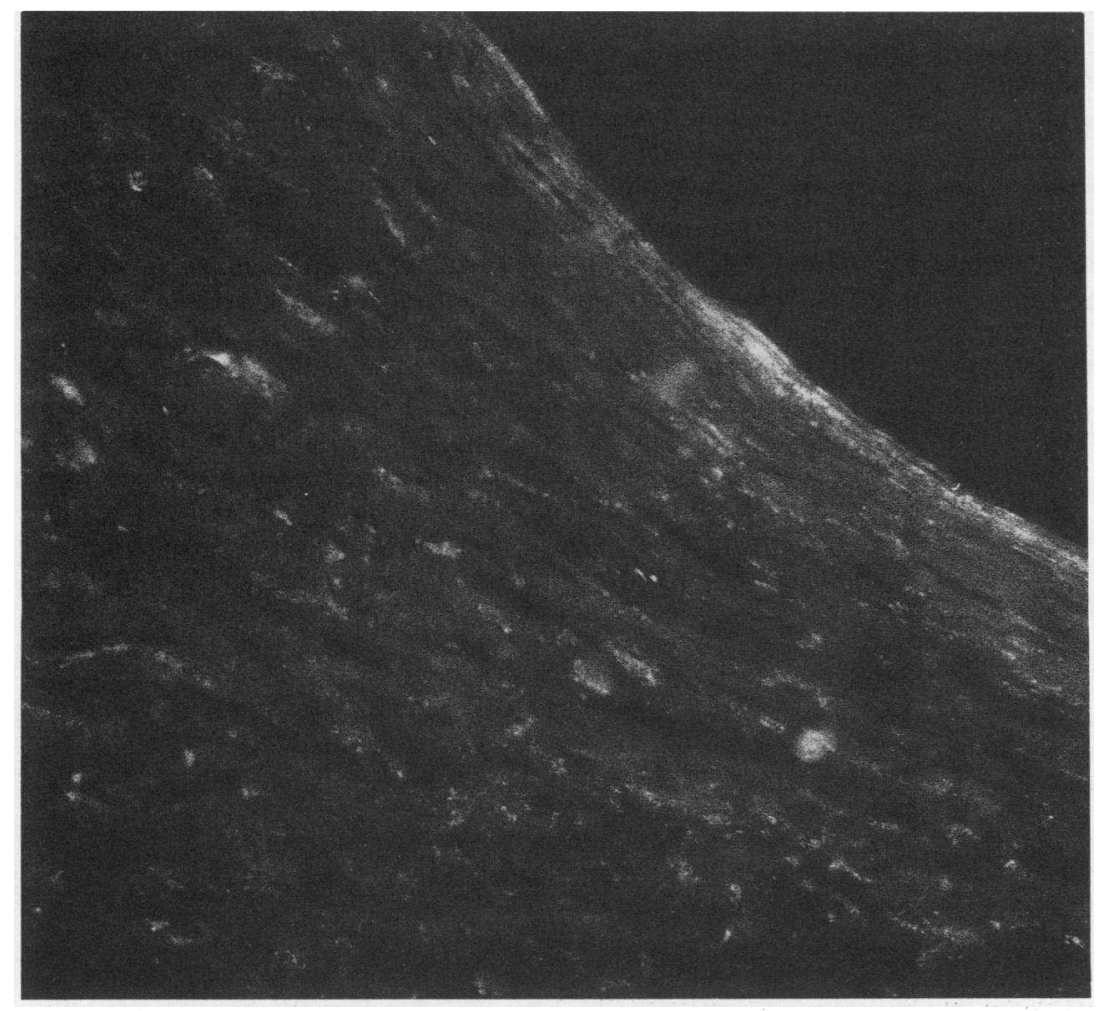

Figure 1. Immunohistochemical localization of DAF in the shoulder region of an advanced human carotid atherosclerotic lesion $(\times 150)$. 

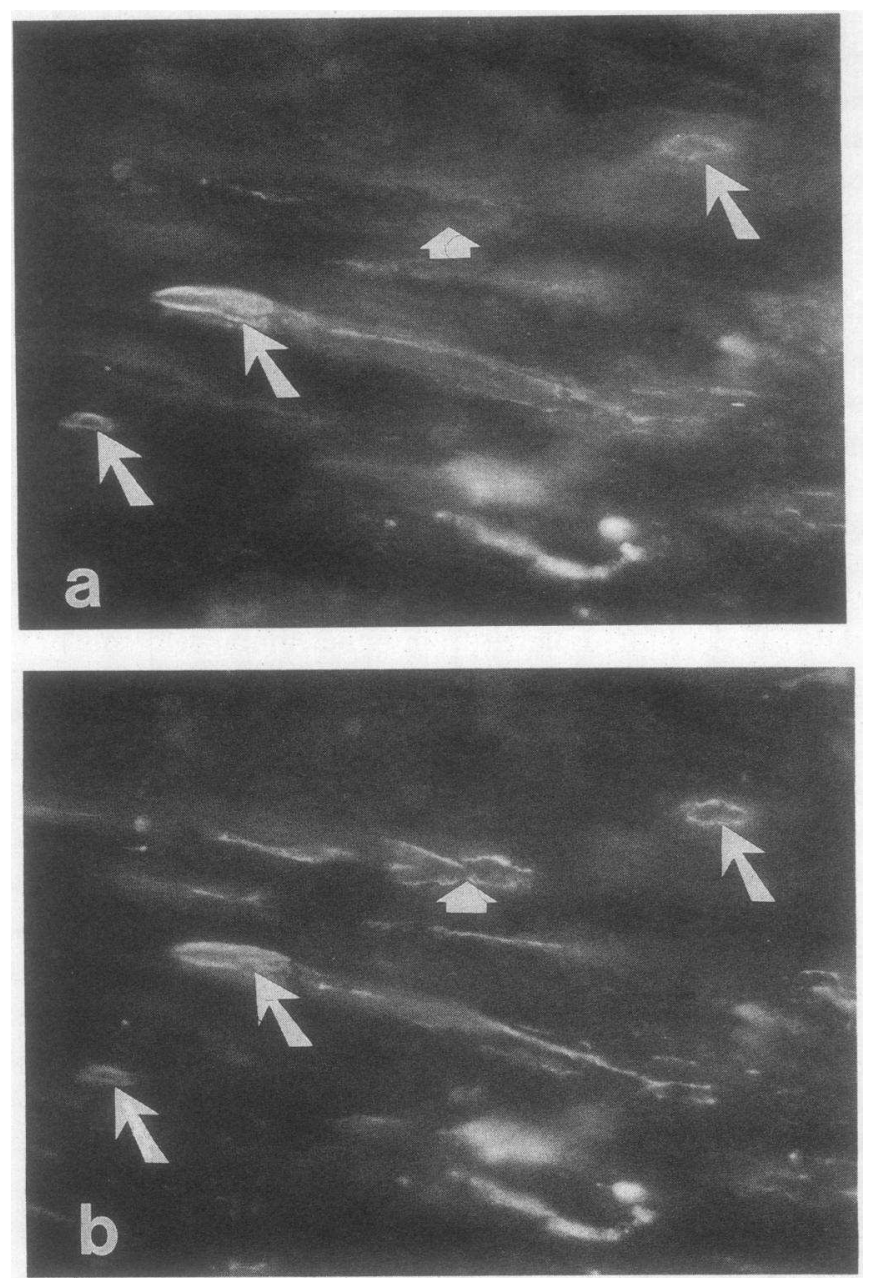

Figure 2. Immunolocalization of DAF to SMC in atherosclerotic lesions by double-staining. Anti-DAF specific immunofluorescence (fluorescein) (a) and anti-SMC myosin immunofluorescence (rhodamine) (b). Arrows indicate examples of DAF-positive SMC and arrowheads indicate DAF-negative, myosin-positive cells $(\times 300)$.

erythrocytes $\left(E^{r}\right)$ are subject to alternative pathway complement mediated-lysis by normal human serum (38) and that DAF is a lipophilic molecule which can insert itself into lipid bilayers (29). Soluble human SMC DAF was obtained by extraction with $1 \%$ SDS in Tris- $\mathrm{HCl}$ buffer. $\mathrm{E}^{\mathrm{r}}$ were then treated with increasing dilutions of DAF containing SMC extracts in order to produce $\mathrm{E}^{\mathrm{r}}$ with varying amounts of human DAF incorporated into their membranes. DAF sensitized $E^{r}$ were then subjected to (MgEGTA dialyzed) human serum and the degree of hemolysis assessed. As shown in Fig. 7, $\mathrm{E}^{\mathrm{r}}$ were protected from complement-mediated lysis as a function of the amount of extract used to sensitize the cells. When $\mathrm{E}^{\mathrm{r}}$ were sensitized with ${ }^{125}$ I-radiolabeled SMC extracts, $0.2 \%$ of the radioactivity was incorporated into the cells supporting that DAF was selectively transferred as previously shown (26). Additionally, the protective effect of extract-sensitized $E^{r}$ was reversed by treating the cells with anti-DAF monoclonal antibodies (Table I). Sensitization reduced hemolysis by $58 \%$, whereas treatment of sensitized $\mathrm{E}^{\mathrm{r}}$ with anti-DAF antibodies restored their susceptibility to complement-mediated hemolysis to within $20 \%$ of unsensitized $\mathrm{E}^{\mathrm{r}}$.
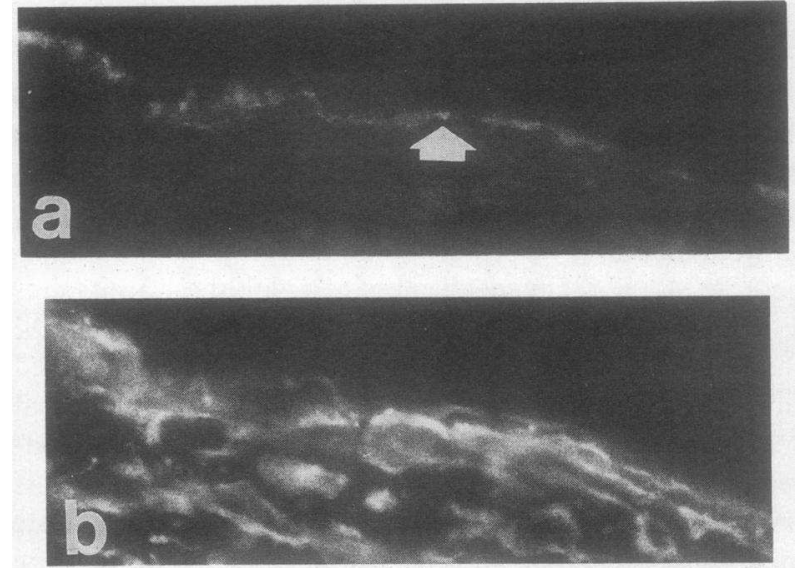

Figure 3. Immunofluorescent detection of $\operatorname{DAF}(a)$ in normal uterine arterial wall occurs only at the lumenal border (arrowhead), yet the medium is rich in SMC $(b)$ as indicated by anti-SMC myosin staining $(\times 300)$.

\section{Discussion}

DAF is a plasma membrane glycoprotein that inhibits autologous complement activation by interfering with $\mathrm{C} 3 / \mathrm{C} 5$ convertase formation $(18,19)$. Obstruction of cell surface convertase formation will aid in protecting cells against terminal
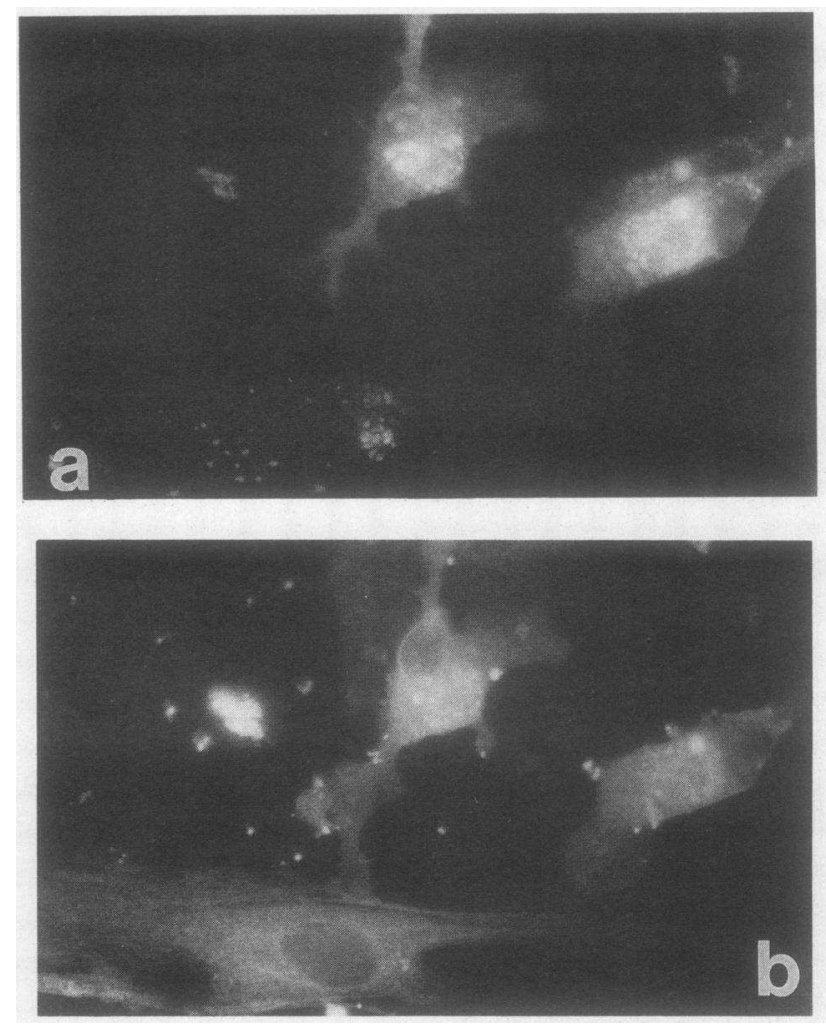

Figure 4. DAF expression by SMC isolated from carotid artery atherosclerotic lesions. Anti-DAF antibodies react with two cells in this field $(a)$ whereas anti-SMC specific myosin stains not only the DAFpositive cells but others as well $(b)(\times 600)$. Note that autofluorescent lipid droplets are collected cytoplasmically in the perinuclear region of the DAF-positive cells. 

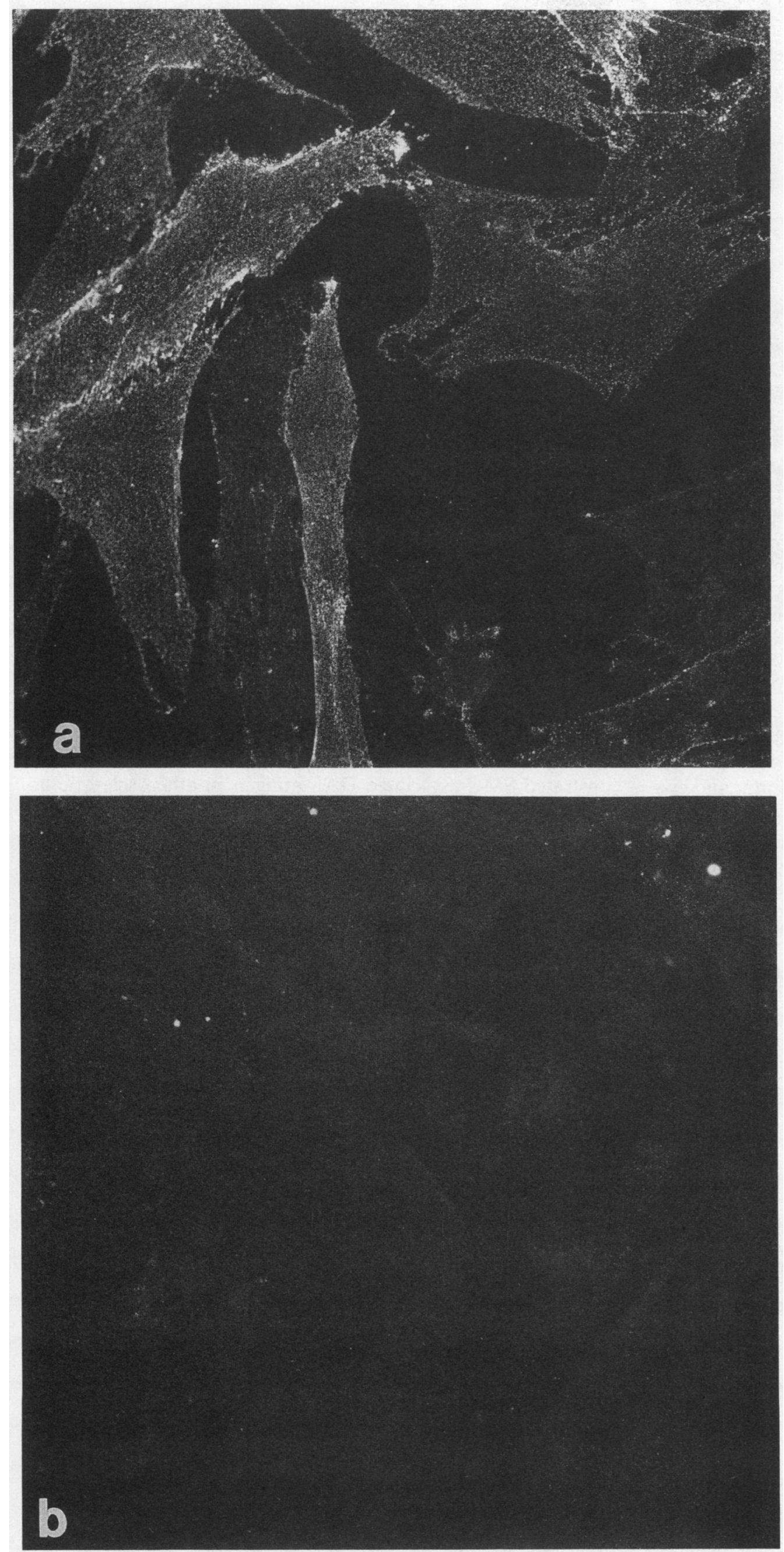

Figure 5. Immunocytochemical demonstration of DAF $(a)$ on cultured SMC versus control antibody staining with anti-CR2 $(b)(\times 600)$. 


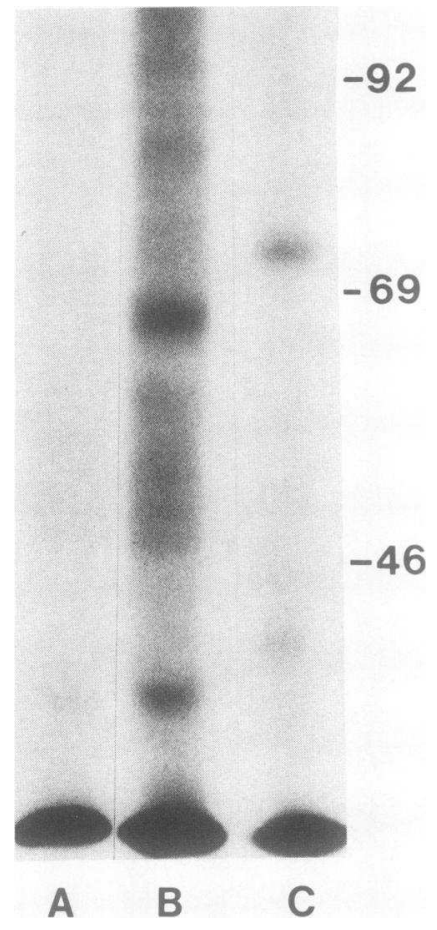

Figure 6. SDS-PAGE autoradiographs of DAF immunoprecipitated SMC extract after surface labeling with ${ }^{125}$ I. Lane $a$, control precipitation with anti-CR2 monoclonal antibody. Lane $b$, immunoprecipitation with anti-DAF monoclonal antibody. Lane $c$, human erythrocyte DAF, immunoprecipitation of ${ }^{125}$ I-labeled cell extract. Molecular weight marker positions shown to right.
Table I. Effect of Anti-DAF Monoclonal Antibodies on the Complement-mediated Hemolysis of SMC Extract-sensitized $E^{r}$

\begin{tabular}{lcc}
\hline \multicolumn{1}{c}{ Experimental condition } & \% Hemolysis* & $\begin{array}{c}\text { \% Protection } \\
\text { from } \\
\text { hemolysis }\end{array}$ \\
\hline Unsensitized $\mathrm{E}^{\mathrm{r}}+$ control antibodies & 30 & mean $\pm S D^{*}$ \\
Sensitized $\mathrm{E}^{\mathrm{r}}+$ antiDAF & 24 & - \\
Sensitized $\mathrm{E}^{\mathrm{r}}+$ control antibodies & 18 & $18 \pm 2.6$ \\
& & $42 \pm 3.8$
\end{tabular}

$E^{r}\left(10^{8} / \mathrm{ml}\right)$ were sensitized with a $1: 10^{3}$ dilution of SMC extract, or dilution buffer $\left(\mathrm{DGVB}^{2+}\right)$, washed and incubated with anti-DAF monoclonal antibodies $(0.25 \mu \mathrm{g} / \mathrm{ml}$ each of clone IA 10 and IIH6) or control monoclonal antibodies of the same IgG subclass $(0.25 \mu \mathrm{g} / \mathrm{ml}$ each of antihuman CR1 and HLA-DR) for $30 \mathrm{~min}$ at $20^{\circ} \mathrm{C}$. After pelleting, the cells were resuspended in GVBMgEGTA at $10^{8} \mathrm{E} / \mathrm{ml}$ and $100 \mu \mathrm{l}$ reacted with $100 \mu \mathrm{l}$ of varying dilutions of GVBMgEGTA-dialyzed normal human serum as shown in Fig. 7. Plots of percent hemolysis versus microliters of serum added, generated curves that were linear between 30 and $70 \mu l$ of serum added. * \% Hemolysis is given at $50 \mu \mathrm{l}$ of serum added.

₹ The average percent hemolysis at 40,50 , and $60 \mu \mathrm{l}$ of serum added for sensitized $E^{r}$ was compared to unsensitized $E^{r}$.

induction of DAF expression on a DAF-negative cell type has not been described. Our immunohistochemical analysis demonstrated SMC-associated DAF antigen in atherosclerotic lesions but an absence of DAF on SMC in normal arterial wall. That DAF in lesions was present on the SMC plasma membrane and not on the surrounding basal lamina was shown by immunostaining of cells isolated from lesions by collagenase digestion. Specific induction of DAF expression is suggested by the fact that many, but not all, SMC in a lesion exhibited DAF and cultured SMC derived from DAF-negative arterial media express DAF.

In contrast to lesional SMC, essentially all SMC grown in culture demonstrated an immunoreactivity to anti-DAF antibodies. Isolation of SMC DAF by immunoprecipitation followed by SDS-PAGE analysis revealed a DAF-specific band at $68 \mathrm{kD}$. Simultaneous immunoprecipitation of $E^{\mathrm{h}}$ DAF produced a band at $70 \mathrm{kD}$. Previous studies have determined a similar 70-kD $M_{\mathrm{r}}$ for $\mathrm{E}^{\mathrm{h}}(17,25,26)$. Human leukocytes and platelets, on the other hand, have a relative molecular mass in the range of 75 to $80 \mathrm{kD}$, neutrophils possess a DAF of $\sim 84$ $\mathrm{kD}(25)$, and human endothelial cells exhibit a DAF molecule of $70 \mathrm{kD}$ (39). The differences in DAF molecular weights between cell types appears to be due to variable posttranslational glycosylation of a common $46-\mathrm{kD}$ precursor molecule (42).

To assess whether vascular SMC DAF possessed functional activity, $E^{r}$ sensitized with SMC DAF extracts were reacted with (MgEGTA dialyzed) normal human serum and the degree of hemolysis assessed. $\mathrm{E}^{\mathrm{r}}$ are activators of the human alternative complement pathway and are not subject to regulation by factors $\mathrm{H}$ and I (38). DAF is a lipophilic molecule with the capacity of inserting into lipid bilayers (29). Hence, passive transfer of DAF into $E^{r}$ can be used as a means of determining the C3/C5 convertase inhibiting ability of DAF (29). It was 
found that $E^{\mathrm{r}}$ treated with SMC extracts were protected from hemolysis by human serum when compared to extract buffertreated $\mathrm{E}^{\mathrm{r}}$ and that protection from hemolysis was related to the concentration of SMC extract used to sensitize the $E^{r}$. Furthermore, selective transfer of DAF from SMC extracts to $\mathrm{E}^{\mathrm{r}}$ was suggested by the incorporation of radioactivity into the $E^{r}$ after treatment with radiolabeled SMC extract. Also, the protection against hemolysis conferred to $\mathrm{E}^{\mathrm{r}}$ from SMC extract exposure was reversed by reacting the sensitized $\mathrm{E}^{\mathrm{r}}$ with antiDAF monoclonal antibodies. The degree to which antibodies reversed the inhibitory action of DAF was comparable to that previously reported (26). We conclude from these experiments that vascular SMC possess a functional DAF species.

Complement activation in a lesion appears to be a consistent and ongoing feature of atherogenesis based on the fact that C5b-9 terminal complexes are present in early as well as advanced lesions (43). Both C5b-9 complexes and DAF are confined to the arterial region of disease involvement, raising the possibility that complement activation products are involved in the induction of DAF expression. On the other hand, since DAF is expressed on proliferating cells in culture, and SMC proliferation is a feature of atherogenesis, regulation of DAF expression may be associated with events surrounding cell proliferation.

Our results indicate that DAF can be induced on a normally DAF-negative cell type and that DAF represents a mechanism for arterial wall complement regulation, in the present instance, in terms of atherosclerotic vascular disease.

\section{Acknowledgments}

We thank Marianne Hådén and Monika Hellstrand for technical assistance and Dr. Jan Holm and Dr. Nils Crona for providing tissue samples. Dr. Seifert was the recipient of a fellowship from the Fogarty International Center of the National Institutes of Health.

This work was supported by grants from the National Institutes of Health (HLO 7356), the Swedish National Association against Heart and Chest Diseases and the Swedish Medical Research Council (6816).

\section{References}

1. Seifert, P. S., and M. D. Kazatchkine. 1988. The complement system in atherosclerosis. Atherosclerosis. 73:91-104.

2. Vlaicu, R., F. Niculescu, H. G. Rus, and A. Cristea. 1985. Immunohistochemical localization of the terminal C5b-9 complement complex in human aortic fibrous plaque. Atherosclerosis. 57:163-177.

3. Niculescu, F., F. Hugo, H. G. Rus, R. Vlaicu, and S. Bhakdi. 1987. Quantitative evaluation of the terminal C5b-9 complement complex by ELISA in human atherosclerotic arteries. Clin. Exp. Immunol. 69:477-483.

4. Vlaicu, R., H. G. Rus, F. Niculescu, and A. Cristea. 1985. Immunoglobulins and complement components in human aortic atherosclerotic intima. Atherosclerosis. 55:35-50.

5. Hansson, G. K., J. Holm, and J. G. Kral. 1984. Accumulation of IgG and complement factor C3 in human arterial endothelium and atherosclerotic lesions. Acta Pathol. Microbiol. Immunol. Scand. 92A:429-435.

6. Cosio, F., R. A. Zager, and H. M. Sharma. 1985. Atheroembolic renal disease causes hypocomplementaemia. Lancet. ii:118-121.

7. Hammerschmidt, D. E., C. S. Greenberg, O. Yamada, P. R. Craddock, and H. S. Jacob. 1981. Cholesterol and atheroma lipids activate complement and stimulate granulocytes. A possible mechanism for amplification of ischemic injury in atherosclerotic states. $J$. Lab. Clin. Med. 98:68-77.
8. Bocan, T. M. A., and J. R. Guyton. 1985. Human aortic fibrolipid lesions. Progenitor lesions for fibrous plaques exhibiting early formation of the cholesterol-rich core. Am. J. Pathol. 120:193-206.

9. Small, P. M. 1988. Progression and regression of atherosclerotic lesions. Insight from lipid physical biochemistry. Arteriosclerosis. 8:103-129.

10. Seifert, P. S., and M. D. Kazatchkine. 1987. Generation of complement anaphylatoxins and C5b-9 by crystalline cholesterol oxidation derivatives depends on hydroxyl group number and position. Mol. Immunol. 24:1303-1308.

11. Kovacsovics, T., J. Tschopp, A. Kress, and H. Isliker. 1985. Antibody-independent activation of $\mathrm{Cl}$, the first component of complement, by cardiolipin. J. Immunol. 135:2695-2700.

12. Hansson, G. K., Lagerstedt, A. Bengtsson, and M. Heideman. 1987. IgG-binding to cytoskeletal intermediate filaments activates the complement cascade. Exp. Cell. Res. 170:338-350.

13. Seifert, P. S., J. L. Catalfamo, and W. J. Dodds. 1988. Complement C5a (desArg) generation in serum exposed to damaged aortic endothelium. Exp. Mol. Pathol. 48:216-225.

14. Baker, P. J., S. Adler, Y. Yang, and W. G. Couser. 1984. Complement activation by heat-killed human kidney cells: formation, activation and stabilization of cell-bound C3 convertases. J. Immunol. 133:877-881.

15. Schäfer, H., D. Mathey, F. Hugo, and S. Bhakdi. 1986. Deposition of the terminal C5b-9 complement complex in infarcted areas of human myocardium. J. Immunol. 137:1945-1949.

16. McManus, L. M., W. P. Kolb, M. H. Crawford, R. A. O'Rourke, F. L. Grover, and R. N. Pinckard. 1983. Complement localization in ischemic baboon myocardium. Lab. Invest. 48:436447.

17. Nicholson-Weller, A., J. Burge, D. T. Fearon, P. F. Weller, and K. F. Austen. 1982. Isolation of a human erythrocyte membrane glycoprotein with decay-accelerating activity for $\mathrm{C} 3$ convertases of the complement system. J. Immunol. 129:184-189.

18. Kinoshita, T., M. E. Medof, and V. Nussenzweig. 1986. Endogenous association of decay-accelerating factor (DAF) with $\mathrm{C} 4 \mathrm{~b}$ and C3b on cell membranes. J. Immunol. 136:3390-3395.

19. Fujita, T., T. Inoue, K. Ogawa, K. lida, and N. Tamura. 1987. The mechanism of action of decay-accelerating factor (DAF). DAF inhibits the assembly of $\mathrm{C} 3$ convertases by dissociating $\mathrm{C} 2 \mathrm{a}$ and $\mathrm{Bb} . J$. Exp. Med. 166:1221-1228.

20. Cole, J. L., G. A. Hously, T. R. Dykman, R. P. MacDermott, and J. P. Atkinson. 1985. Identification of an additional class of C3binding membrane proteins on human peripheral blood leucocytes and cell lines. Proc. Natl. Acad. Sci. USA. 82:859-863.

21. Seya, T., J. R. Turner, and J. P. Atkinson. 1986. Purification and characterization of a membrane protein (gp 45-70) that is a cofactor for cleavage of C3b and C4b. J. Exp. Med. 163:837-855.

22. Fearon, D. T. 1979. Regulation of the amplification C3 convertase of human complement by an inhibitory protein isolated from human erythrocyte membrane. Proc. Natl. Acad. Sci. USA. 76:58675871.

23. Iida, K., and V. Nussenzweig. 1983. Complement receptor is an inhibitor of the complement cascade. J. Exp. Med. 153:1138-1150.

24. Medof, M. E., E. I. Walter, J. L. Rutgers, D. M. Knowles, and V. Nussenzweig. 1987. Identification of the complement decay-accelerating factor (DAF) on epithelium and glandular cells and in body fluids. J. Exp. Med. 165:848-864.

25. Nicholson-Weller, A., J. P. March, C. E. Rosen, D. B. Spicer, and K. F. Austen. 1985. Surface membrane expression by human blood leukocytes and platelets of decay-accelerating factor, a regulatory protein of the complement system. Blood. 65:1237-1244.

26. Kinoshita, T., M. E. Medof, R. Silber, and V. Nussenzweig. 1985. Distribution of decay-accelerating factor in the peripheral blood of normal individuals and patients with paroxysmal nocturnal hemoglobinuria. J. Exp. Med. 162:75-92. 
27. Fearon, D. T. 1980. Identification of the membrane glycoprotein that is the $\mathrm{C} 3 \mathrm{~b}$ receptor of the human erythrocyte, polymorphonuclear leucocyte, B lymphocyte and monocyte. J. Exp. Med. 153:20-30.

28. Wilson, J. G., T. F. Tedder, and D. T. Fearon. 1983. Characterization of human $\mathrm{T}$ lymphocytes that express the $\mathrm{C} 3 \mathrm{~b}$ receptor. $J$. Immunol. 131:684-689.

29. Medof, M. E., T. Kinoshita, and V. Nussenzweig. 1984. Inhibition of complement activation on the surface of cells after incorporation of decay-accelerating factor (DAF) into their membranes. J. Exp. Med. 160:1558-1578.

30. Rosse, W. F. 1984. The control of complement activation by the blood cells in paroxysmal nocturnal hemoglobinuria. Blood. 67:268-269.

31. Skalli, O., P. Ropraz, A. Trzeciak, G. Benzonana, D. Gillessen, and G. Gabbiani. 1986. A monoclonal antibody against $\alpha$-smooth muscle actin. A new probe for smooth muscle differentiation. J. Cell Biol. 103:2787-2796.

32. Larson, D. M., K. Fujiwara, R. W. Alexander, and M. A. Gimbrone, Jr. 1984. Heterogeneity of myosin antigenic expression in vascular smooth muscle in vivo. Lab. Invest. 50:401-407.

33. Jonasson, L., J. Holm, O. Skalli, G. Gabbiani, and G. K. Hansson. 1985. Expression of class II transplantation antigen on vascular smooth muscle cells in human atherosclerosis. J. Clin. Invest. 76:125-131.

34. Jonasson, L., J. Holm, O. Skalli, G. Bondjers, and G. K. Hansson. 1986. Regional accumulations of $T$ cells, macrophages, and smooth muscle cells in the human atherosclerotic plaque. Arteriosclerosis. 6:131-138.

35. Fager, G., G. K. Hansson, P. Ottosson, B. Dahllöf, and G.
Bondjers. 1988. Human arterial smooth muscle cells in culture. Effects of platelet-derived growth factor and heparin on growth in vitro. Exp. Cell. Res. 176:319-335.

36. Ross, R., T. N. Wight, E. Strandness, and B. Thiele. 1984. Human atherosclerosis. I. Cell constitution and characteristics of advanced lesions of the superficial femoral artery. Am. J. Pathol. 14:7993.

37. Gown, A., T. Tsukada, and R. Ross. 1986. Human atherosclerosis. II. Immunocytochemical analysis of the cellular composition of human atherosclerotic lesions. Am. J. Pathol. 125:191-207.

38. Fearon, D. T., and K. F. Austen. 1977. Activation of the alternative complement pathway with rabbit erythrocytes by circumvention of the regulatory action of endogenous control proteins. J. Exp. Med. 146:22-33.

39. Asch, A. S., T. Kinoshita, E. A. Jaffe, and V. Nussenzweig. 1986. Decay-accelerating factor is present on cultured human umbilical vein endothelial cells. J. Exp. Med. 163:223-226.

40. Berger, M., and M. E. Medof. 1987. Increased expression of complement decay-accelerating factor during activation of human neutrophils. J. Clin. Invest. 79:214-220.

41. Davis, L. S., S. S. Patel, J. P. Atkinson, and P. E. Lipsky. 1988. Decay-accelerating factor functions as a signal transducing molecule for human T cells. J. Immunol. 141:2246-2252.

42. Lublin, D. M., J. Krsek-Staples, M. K. Pangburn, and J. P. Atkinson. 1986. Biosynthesis and glycosylation of the human complement regulatory protein decay-accelerating factor. J. Immunol. 137:1629-1635.

43. Niculescu, F., H. G. Rus, and R. Vlaicu. 1987. Immunohistochemical localization of C5b-9, S-protein, C3d and apolipoprotein B in human arterial tissues with atherosclerosis. Atherosclerosis. 65:1-11. 